The International Journal of Social Sciences

Vol. 2, Issue. 3, Sept 2021

P-ISSN: 2807-193X | E-ISSN: 2746-4393

\title{
PROJECT CITIZEN LEARNING MODEL BASED ON PORTFOLIO FOR EDUCATION COMPETENCE TOWARDS SOCIETY 5.0
}

\author{
Helminsyah \\ Bina Bangsa University Getsempena, Indonesia \\ helmi@bbg.ac.id \\ Musdiani $^{2}$ \\ Bina Bangsa University Getsempena, Indonesia
}

Ali Mustadi ${ }^{3}$

Yogyakarta State University, Indonesia

Anwar Monday 4

Yogyakarta State University, Indonesia

\begin{abstract}
This research intends to develop a portfolio-based project citizen model to strengthen the social competence of educators towards society 5.0. This research design uses the Research and Development method in this research in grade IV elementary schools in SDN City, Banda Aceh, teachers, and learning experts. Information is combined with methods of monitoring, in-depth debriefing, and selection. Information analysis was tried by quantitative methods, namely descriptive and comparative. The results obtained are the acquisition of Measuring competence and the acquisition of a quality learning model The results of the expert's assessment of the quality of the Portfolio display number 3, 38 (in good type), from the quality of the form it proves the number 3.04 (in good type), on the contrary from the point of view of organizing the module the score is: stability of 2.92 (pretty good), shape of 3, 13 (good), organization of 3, 25 (good), shape and dimensions of 2, 63 (pretty good) The results of the feasibility trial (trial) on students prove the quality of proving the number 3, 28 (in good type), From the quality of form and energy, it proves that the score is 3.30 (in good category), on the contrary from the organizing part of the module, the score is: 3.22 (good). Thus, the portfolio-based Project citizen model to strengthen the social competence of educators towards society 5 is feasible to use.
\end{abstract}

Keywords: Project Citizen Learning Model, Portfolio For Education Competence, Towards Society 5.0 


\section{A. Introduction}

Learning is one of the important aspects for elementary schools that is even more important in ensuring the success of students (Widodo et al., nd). Therefore, an efficient learning method is needed, namely upgrading that can provide students to achieve the specified competencies supported by adequate facilities. A quality learning model. (Njiku, 2020)

However, the observations that the researchers made in the learning process at the Banda Aceh State Elementary School showed that the stages of the learning process were still very simple.

This concern is still compounded by the pattern of theoretical learning which is generally dominated by lectures and does not involve students. (Chen, 2021) The lack of learning model patterns used makes it difficult for students to digest abstract concepts to be translated into the ability to measure teacher and student competencies. (Ambaryani \& Airlanda, 2017)

The various problems above require immediate resolution so that the quality of the graduates produced can be maintained. Portfolio-based project citizens are the most suitable learning alternatives according to the characteristics of the problems that occur.

Based on the background of the problem, the formulation of the research problem is: (1) How is the formulation of a portfolio-based Project citizen model to strengthen the social competence of educators towards a society? 5.0. ? (2) How to develop a learning model of a model citizen-based project portfolio to strengthen the social competence of educators towards society 5.0 competencies that have been formulated and tested in theoretical and empirical, and (3) What is the feasibility study model of citizen-based project portfolio to strengthen the social competence of educators towards society 5.0.

\section{B. Method}

The research aims to design, create and develop a portfolio-based Project citizen model to strengthen the social competence of educators towards society 5. (Prasetyo, 2008) The study was designed using a Research and Development approach with the following stages: (1) selection of learning models through literature review, and field survey (2) planning; (3) socialization to determine the form and model of learning; (5) validation; (6) trial. (Subroto et al., 2020) 


\section{Finding and Discussion}

\section{Finding}

The feasibility of a portfolio-based Project citizen learning model to strengthen educators' social competence towards society 5.0 can be seen from the results of expert validation and the results of limited empirical tests. Validation is carried out on the substance of the material. The expert assessment and approval can be presented in the following table.

\begin{tabular}{|c|l|c|}
\hline No & \multicolumn{1}{|c|}{ Aspect Of Evaluation } & Score \\
\hline 1 & Suitability indicators of success & 3.50 \\
\hline 2 & to match Project Citizen's Model development syntax & 2.75 \\
\hline 3 & Learning model orientation & 2.75 \\
\hline 4 & Suitability choose problem & 3.50 \\
\hline 5 & Reflecting student learning experiences & 3.00 \\
\hline 6 & $\begin{array}{l}\text { Materials with learning objectives refer to aspects of student } \\
\text { development }\end{array}$ & 3.25 \\
\hline 7 & Ease of choosing language Average & 2.50 \\
\hline & \multicolumn{1}{|c|}{ A } & 3.04 \\
\hline
\end{tabular}

Based on the table above, it can be seen that the overall learning model has reached 3.04 in the good category. It is observed from the points that the overall number is above 3 and is in the good category. Furthermore, the portfolio-based learning model is presented in the table below:

\begin{tabular}{|c|l|c|}
\hline No & \multicolumn{1}{|c|}{ Evaluation Aspect } & Score \\
\hline 1 & There is a clear formulation of competency objectives & 3.25 \\
\hline 2 & $\begin{array}{l}\text { Emphasizing on the achievement of competencies that are in } \\
\text { accordance with needs }\end{array}$ & 3.50 \\
\hline 3 & Easy-to-use study guide & 3.50 \\
\hline 4 & Loading knowledge according to the unit of competence & 3.50 \\
\hline 5 & Loading skills according to the unit of competence & 3.50 \\
\hline 6 & Contains a clear attitude to demonstrate & 3.25 \\
\hline 7 & Easy to understand language & 3.75 \\
\hline 8 & $\begin{array}{l}\text { Assignments and exercises are sufficient to help achieve } \\
\text { competence }\end{array}$ & 3.30 \\
\hline 9 & Tasks and exercises according to the unit of competence & 3.50 \\
\hline 10 & Learning materials according to the level of students & 3.00 \\
\hline
\end{tabular}




\begin{tabular}{|c|l|c|}
\hline 11 & Allows students to take their own initiative in learning & 3.50 \\
\hline 12 & Allows students to learn independently & 3.50 \\
\hline 13 & The material is organized in a systematic order & 3.25 \\
\hline 14 & There is an assessment section (testing) & 3.50 \\
\hline 15 & The assessment instrument is easy to understand & 3.25 \\
\hline 16 & Instructions on the assessment are easy to understand & 3.25 \\
\hline 17 & Allows participants to do their own assessment & 3.50 \\
\hline & Average & 3.38 \\
\hline
\end{tabular}

Based on the table above, it can be seen that the development of a portfolio-based Project citizen learning model to strengthen the social competence of educators towards society 5.0 is 2, 92 good categories. there are some that need correction, namely in terms of letters that are too small, and the layout, while in terms of the use of words it feels fulfilled or has been good. In terms of shape, the number shown is 3, 13, it proves that the form of arrangement used is good. The thing that needs to be fixed is that the columns (single or multi) on the page match and match the dimensions of the paper used. In terms of module organization, the number achieved is $3.25 \mathrm{ingood}$ form. When observed from the constituent grains, all of them have a number greater than 3 . That way the totality of organizing the modules is listed in good type. In terms of shape and dimensions, the total number reaching 2.63 proves a good breed.

At the end of the assessment instrument, experts and experts provide final recommendations from the design of the model, the results of the suggestions can be shown in the following table

\begin{tabular}{|c|l|c|}
\hline No & \multicolumn{1}{|c|}{ Average } & \multicolumn{1}{|c|}{$\%$} \\
\hline 1. & Can be used to fill important material without repair & 25 \\
\hline 2. & Can be used to fill important material with improvements & 75 \\
\hline 3. & Can be used as a reference without repair & 25 \\
\hline 4. & Cannot be used as material in models in learning or references & 75 \\
\hline 5. & Can be used as a reference with improvements & 0 \\
\hline
\end{tabular}

Based on the chart above, the Project citizen portfolio-based learning model to strengthen the social competence of educators towards society 5.0 is still improving. not 
only that, there was 1 expert who provided input as a learning model to be used as a reference.

Students' assumptions about the portfolio-based Project citizen learning model to strengthen the social competence of educators towards society 5.0. student trials of learning can be described as follows:

a. As many as 93, 33\% of students said learning was good, and 6, 67\% reported it was similar to practicing alone.

b. As many as $66,67 \%$ of students said the description and explanation by the teacher was very good

c. As many as $73.33 \%$ of the students stated that they were very happy with the learning model

d. A total of $66.67 \%$ of students stated that the skills obtained from learning.

e. All students (100\%) stated that learning was happy with love and students asked to study in the future as it is currently being done.

\section{Discussion}

Based on the research results of the portfolio-based Project citizen learning model to strengthen the social competence of educators towards society 5.0, it can be said that students deserve to be used even though there are small improvements before being widely disseminated

\section{Conclusion}

This research has been successful in developing the results of input from experts proving that all of them agree on the feasibility of the portfolio-based Project citizen learning model to strengthen the social competence of educators towards a society 5.0. However, there are still some things that need to be improved. On the other hand, the test results on students all prove to be of good quality. society 5.0 in elementary schools as an innovation for upgrading according to the character of students.

\section{Bibliography}

Ambaryani, A., \& Airlanda, G. S. (2017). Pengembangan Media Komik Untuk Efektifitas dan Meningkatkan Hasil Belajar Kognitif Materi Perubahan Lingkungan Fisik. Jurnal Pendidikan Surya Edukasi, 3(1), 19-28. doi:10.37729/jpse.v3i1.3853 
Chen, W., Tan, J. S., \& Pi, Z. (2021). The Spiral Mmodel of Collaborative Knowledge Improvement: an Exploratory Study of a Networked Collaborative Classroom. International Journal of Computer-Supported Collaborative Learning, 16(1), 7-35. doi:10.1007/s11412-021-09338-6

Erlanda Nathasia Subroto, A. Q. (2020). Efektivitas Pemanfaatan Komik sebagai Media Pembelajaran Matematika. Jurnal Pendidikan: Teori, Penelitian, Dan Pengembangan, 5(2), 135-141. doi:10.17977/jptpp.v5i2.13156

Njiku, J., Mutarutinya, V., \& Maniraho, J. F. (2020). Developing Technological Pedagogical Content Knowledge Survey Items: A Review of Literature. Journal of Digital Learning in Teacher Education, 36(3), 150-165. doi:10.1080/21532974.2020.1724840

Prasetyo, I. (2008). Pengaruh Gaya Kepemimpinan Terhadap Kinerja. Jurnal Neo-Bisnis, 2(2), 1-7.

Susilo Tri Widodo, R. R. (2018). Pengembangan Model Pembelajaran Project Citizen Berorientasi Civic Knowledge, Civic Disposition, dan Civic Skill Sebagai Inovasi Dalam Mata Kuliah Pendidikan PKN SD. PKn Progresif: Jurnal Pemikiran dan Penelitian Kewarganegaraan, 13(1), 23-36. doi:10.20961/pknp.v13i1.23262 